\title{
Impact of Audit Committee Adoption and its Characteristics on Financial Performance: Evidence from 100 French Companies
}

\author{
Wided Bouaine ${ }^{1} \&$ Yosr Hrichi ${ }^{2}$ \\ ${ }^{1}$ Assistant Professor, Higher Institute of Accountancy and Corporate Management, University of Manouba, Campus \\ Universitaire 2010, Manouba, Tunisia \\ 2 Assistant Professor, Faculty of Economics and Management of Nabeul, University of Carthage, Campus \\ Universitaire Mrezga 8000, Nabeul, Tunisia \\ Correspondence: Yosr Hrichi, Assistant Professor, Faculty of Economics and Management of Nabeul, University of \\ Carthage, Campus Universitaire Mrezga 8000, Nabeul, Tunisia. E-mail: yosr.hrichi@fsegn.u-carthage.tn
}

Received: December 2, 2018

Accepted: December 24, 2018

Online Published: January 8, 2019

doi:10.5430/afr.v8n1p92

URL: https://doi.org/10.5430/afr.v8n1p92

\begin{abstract}
The aim of this paper is to examine the impact of legal creation of audit committees on financial firm performance. Precisely, we examine the impact of the establishment of audit committee, following the enactment of Ordinance No. 2008-1278, on financial firm market performance. Moreover, we investigate whether the audit committee characteristics such as independence of the members of the audit committees, the size; the accounting and financial expertise of the committee members as well as the frequency of audit committee meetings determine financial performance.

We choose two measures for performance namely ROE and ROA. We conduct a panel study for a sample of 100 French companies listed on the Paris Stock Exchange from 2007 to 2015.

The results show that the appearance of a legal text pushes the establishment of the committee but has no significant effect on the company's performance. This can be explained by the strong voluntary adoption of the audit committee following the publication of the Viénot Reports (Saada, 1998).
\end{abstract}

Keywords: financial performance, legal adoption, characteristics of the audit committee

\section{Introduction}

Recurrent crises caused mainly by the presence of illegal political funding, by the discovering of doubtful financial transactions and the multiplication of fraud cases has had a significant impact on the implementation of audit committee and its characteristics (Eichenseher and Schields, 1985). Due to the loss of confidence in the quality of accounting information and auditing, several countries has an established code of governance or codes of best of practices. Amongst these practices, there is some evidence that audit committees strength the credibility of financial information as its principal mission is to oversee the preparation of financial reports, the effectiveness of internal control procedures.

The implementation of the audit committee on financial firm performance remains an interesting question of research. The literature investigating the impact of audit committee on financial firm performance can be divided into two groups. The first strand of literature show strong evidence audit committee and financial firm performance (Weir, Laing, McKnight, 2002; AlMatrooshi, Al-Sartawi, Sanad, 2016).

Following these studies the implementation of an audit committee increase the credibility of financial information, reduces the cost of capital and improves financial firm performance (Arslan, Zaman, and Maliik Mehmood, 2014; velvet, 2017).

The second strand of literature has been interested on the impact of the characteristics of the audit committee on the financial performance such as the independence of the committee (Nuryanah and Islam, 2011; Chen and Li, 2013; Hamdan and al., 2013; Saibaba and Ansari, 2013; Al-Mamun and al., 2014; Guo and Yeh, 2014; Dinu and Nedelcu, 2015; Gurusamy, 2017), the size of the committee (Chong, 2005; Mak and Kusnadi, 2005; ; Aldamen and al., 2012) expertise in finance and in accounting of the committee members (Abernathy and al, 2014; Singhvi and al., 2013; 
Guo and Yeh, 2014) and the number of committee meetings (Bedard and Gendron, 2010; Saibaba and Ansari, 2013; Nedelcu Dinu, 2015).

The French context is a bit particular in the case that before the entry into force of Directive 2006/43/ EC published in May 2006 and its transposition into French law by Order No. 2008-1278 of December 8th, 2008, the French companies were not compelled by law to set up an audit committee.

The main contributions of this paper are two folds. First, we investigate the impact of the ordinance No. 2008-1278 French law that obliges listed companies to appoint an audit committee, on financial firm performance. This first objective enables us to assess whether the legal establishment of the audit committee has significantly affected financial performance of listed French companies and on which direction is the effect. Second, it examines how the audit committee characteristics impact the financial firm performance.

For robustness, we two proxies of financial performance namely return on assets (ROA), return on equity (ROE). The empirical study uses a data set that covers a period of nine years. Two years correspond to the period of voluntary adoption (2007 -2008) and nine years that correspond to the period of compulsory adoption of the audit committee (2009-2015). A panel data method with fixed effects is used to examines the main questions of the paper for a sample of 100 French companies.

The rest of the paper is organized as follow. Section two describes briefly the literature review about the relationship between audit committee and its characteristics with firm performance and the hypothesis to examine. Section three presents the data, variables measurement, models specifications and the econometrics approaches employed. Section four discuss the results and presents some policy implications.

\section{Impact of Audit Committee Characteristics on Firm Performance}

\subsection{Audit Committee and Firm Performance}

The audit committee is a mechanism of additional control which ensures the interests of shareholders (Klein Rezaee 1998 and 2009). The main role of these committees is to act as a governance mechanism and as an independent observer, which allows to mitigate problems of agency and to maximize business performance (Rezaee, 2009; Aldamen and al., 2012; Chen and Li, 2013). Thus, the adoption of audit committees increases shareholders' confidence in the financial reports of the company (Piot and Janin, 2007). Similary, the capital market react positively to the adoption of audit committees within the directors boards (Heenetigala and Armstrong, 2011; Arslan, Zaman, and Mehmood, 2014).

Therefore, we stat the following hypothesis:

H1. Adopting an audit committee influence significantly the performance of French companies.

\subsection{Audit Committee Characteristics and Firm Performance}

The impact of the characteristics of the audit committee on corporate performance has been widely examined in previous empirical studies, especially in the American context (Godard, 2002; Aldamen and al., 2012; Velte, 2017).

In the French context, only few studies have investigated this issue of audit committee characteristics on firm performance (Maraghni and Nekhili, 2014). So we will examine the impact of the independence, size, skills and diligence of audit committee characteristics on the financial firm performance.

\subsubsection{The Independence of Audit Committee Members}

The empirical literature consider the independence of audit committee members as one of the most important characteristic required in the audit committee to ensure a good quality of financial information (Chtourou and al., 2004).The independence of directors will allow the audit committee members to properly conduct their oversight role. So, several studies in many contexts (Germany, Spain, UK, France, Belgium, Australia, Canada, Jordan, India, Indonesia, Malaysia, China, Bahrain, and Tunisia) show that the presence of outside directors in the audit committee can reduce the opportunistic behavior of managers, improves corporate transparency as well as the quality of information by reducing the fraud in the financial statements (Parker and Peters, 2003; Vlaminck and Sarens, 2015; Sultana, Singh, Mitchell and Zahn, 2015) and improving the performance (Nedelcu and Dinu, 2015; Kallamu and Saat, 2015). Therefore, we put forward the following hypothesis:

H2. The independence of the members of the audit committee is positively correlated with the performance of French companies. 


\subsubsection{The Size of the Audit Committee}

The second audit committee characteristic largely used and examined in the empirical literature is the size of the audit committee. For instance, Chong (2005), Mak and Kusnadi (2005) among many others suggest that the size of the audit committee have a significant impact on company's performance.

So small audit committees are more effective in protecting the interests of shareholders and to ensure a good quality of financial statements (Dezoort and al., 2002).

Aldamenet al. (2012) confirms that large audit committee is not effective and has no effect on firm performance. Thus, the following hypothesis is stated,

H3. The size of the audit committee negatively affects the performance of French companies.

\subsubsection{The Competence of Audit Committee}

As the primary role of the audit committee is to control the quality of the financial reporting, then it is important to test the impact of the skills of the audit committee on firm performance (Lee and Stone 1997). Yang and Krishnan (2005) recommend that the members must have accounting and financial skills.

Thus, an audit committee with at least one member with expertise in finance and accounting is likely to increase the relevance of earnings (Qin, 2007) and improve the quality of financial information (McDaniel, Martin and Maines 2002). Most studies show that financial expertise has an impact on the earning quality and improves the timeliness of financial reporting (Mitchelle and Zhan, 2015; Kallamu and Saat, 2015; Velte, 2017). Consequently, this will improve the company's financial performance (DeZoort 1998; Dinu and Nedelcu, 2015). So, we stat this hypothesis:

H4. The accounting and financial expertise of the members of the audit committee positively affects the performance of French companies.

\subsubsection{The Diligence of Audit Committee}

The frequency of annual meetings of the audit committee is a potential indicator of the effectiveness of the audit committee (Menon and Williams, 1994). A greater number of meetings is considered as a good indicator of the audit committee to better achieve their goals (DeZoort and al. 2002; and Bedard and Gendron, 2010). However, it is important to note that based on the agency theory, the number of meetings can be beneficial to the company only if the benefits obtained from an additional meeting excess of the incurred costs. Moreover, the literature does not recommend a typical number of meetings. For instance, in the United States, the audit committees must meet at least four times a year (Stewart and Munro, 2007). This number of frequency can improve the relevance of earnings, detect fraud (Beasley and al., 2000) and improve the performance. Then, based on previous studies we state the following hypothesis:

H5. The frequency of meetings of the members of the audit committee positively affects the performance of French companies.

\section{Empirical Methodology}

This empirical study is conducted on a sample of 100 French companies listed on the Paris Stock Exchange during the period from 2007 to 2015 . The choice of the period is motivated by the fact that it covers the years of voluntary adoption (2007-2008) and compulsory adoption of the audit committee (2009-2015). The financial institutions are excluded from the original sample due to their specific accounting and regulatory practices. We have also excluded some newly listed companies for problem of unavailability of the data. This data was collected from annual reports available online in the official sites of the concerned companies.

\subsection{Data Description}

To examine the impact of audit committees adoption and their characteristics on financial firm performance, we have used two variables as proxies of financial firm performance namely the ROE and the ROA. Regarding the other variables, they are used as explicative variables. The table 1 presents all the variables. 
Table 1. Variables description and measurement

\begin{tabular}{|c|c|c|}
\hline Variable & Symbol & Measure \\
\hline The return on Assets & ROA & Operating income divided by Total Assets \\
\hline The return on equity & ROE & Net income divided by shareholders' equity \\
\hline $\begin{array}{l}\text { The voluntary or mandatory } \\
\text { adoption of the Audit } \\
\text { Committee }\end{array}$ & ADOP & $\begin{array}{l}\text { It takes the value } 1 \text { if the firm has established } \\
\text { an audit committee under the } 2009 \text { law and } 0 \\
\text { otherwise. }\end{array}$ \\
\hline $\begin{array}{l}\text { The size of the board or } \\
\text { supervisory }\end{array}$ & Size_B/S & Number of directors present in the Council \\
\hline $\begin{array}{l}\text { The independence of the } \\
\text { audit committee }\end{array}$ & IND_AC & $\begin{array}{l}\text { The proportion of independent directors who } \\
\text { are members of the audit committee. }\end{array}$ \\
\hline The size of the audit committee & SIZE_AC & $\begin{array}{l}\text { The proportion of directors who are members } \\
\text { of the audit committee. }\end{array}$ \\
\hline $\begin{array}{l}\text { The competence of the audit } \\
\text { committee }\end{array}$ & COM_AC & $\begin{array}{l}\text { The relationship between members with } \\
\text { expertise in accounting and the total number of } \\
\text { the audit committee. }\end{array}$ \\
\hline $\begin{array}{l}\text { The diligence of the audit } \\
\text { committee }\end{array}$ & ACT_AC & The number of audit committee meetings \\
\hline $\begin{array}{l}\text { The quality of the external } \\
\text { auditor }\end{array}$ & BIG 4 & $\begin{array}{l}\text { It takes the value } 1 \text { if the firm employs two } \\
\text { commissioners who belong to the Big } 4 \text { and } 0 \\
\text { otherwise. }\end{array}$ \\
\hline The company size & SIZE & Logarithm of total assets. \\
\hline The level of debt & LD & $\begin{array}{l}\text { The ratio between the accounting value of the } \\
\text { debt and the total assets. }\end{array}$ \\
\hline
\end{tabular}

\subsection{Research Models}

To examine the impact of the audit committee on firm performance for a 100 French listed companies during the period from 2007 to 2015, we will use a panel data approach. Two empirical specifications have been considered in this study. The first specification that we call the audit committee adoption specification is used to assess the impact of the adoption of an audit committee on financial firm performance. This first specification is given by,

\subsection{The Audit Committee Adoption Specification}

$$
P E R F_{i t}=\alpha_{0}+\alpha_{1} A D O P_{i t}+\alpha_{2}\left(S I Z E_{-} B / S\right)_{i t}+\alpha_{3} B I G 4_{i t}+\alpha_{4} S I Z E_{i t}+\alpha_{5} L D_{i t}+\epsilon_{i t}
$$

Where $P E R F_{i t}$ is the firm performance for firm $i$ at time $t$. PERF can take one of two firm financial performance proxies, the price earnings ratio, return on assets ROA or the returns on equity, ROE. ADOP $\left(S I Z E_{-} B / S\right)_{i t}, B I G 4_{i t}, S I Z E_{i t}$ and $L D_{i t}$ are the explicative variables $\alpha=\left(\alpha_{0}, \ldots, \alpha_{7}\right)$ is the vector parameter to estimate and $\epsilon_{i t}$ is the error term.

\subsection{The Audit Committee Characteristics Specification}

The second specification that we call the audit committee characteristics specification, is used to examine the effects of audit committee characteristics on firm performance. This second specification is given by,

$$
\begin{gathered}
P E R F_{i t}=\alpha_{0}+\alpha_{1} I N D_{-} A C_{i t}+\alpha_{2}\left(S I Z E_{-} A C\right)_{i t}+\alpha_{3}\left(C O M_{-} A C\right)_{i t}+\alpha_{4}\left(A C T_{-} A C\right)_{i t}+\alpha_{5} B I G 4_{i t}+\alpha_{6}\left(S I Z E_{-} B / S\right)_{i t} \\
+\alpha_{7} S I Z E_{i t}+\alpha_{8} L D_{i t}+\epsilon_{i t}
\end{gathered}
$$

Where $P E R F_{i t}$ is the firm performance for firm $i$ at time $t$. PERF can take one of two firm financial performance proxies, IND_AC $i t$, $\left(S I Z E_{-} A C\right)_{i t}, C O M_{-} A C_{i t}, C O M_{-} A C_{i t}$ and $A C T_{-} A C_{i t}$ are the explicative variables $\alpha=\left(\alpha_{0}, \ldots, \alpha_{7}\right)$ is the vector parameter to estimate and $\epsilon_{i t}$ is the error term. 


\section{Results Discussion}

\subsection{Descriptive Statistics}

The results of the descriptive statistics are reported in table 2 below. Indeed, the results indicate that French companies in our sample have an average of the return on assets that is negative $-0.147 \%$. The difference in the results between mean and median is an indicator of the presence of very large negative values of return on assets in the sample. This can be explained by the fact that our period of analysis includes the subprime crises.

Similarly, ROE measures the ability of a company to generate profits from its net equity which does not exceed a minimum of -12.211 .631 with an average not exceeding 0.605 .

The companies in our sample have audit committees with an average size of 3 directors. This variable varies between 2 and 7 administrators.

In addition, the average of independence of members of the audit committee shall not exceed 0.60 which shows the existence of at least one independent member in the audit committee. In our sample, we can see that the average audit committee members are skilled in accounting and / or finance (average $=0.477$ ). In addition, the number of meetings of the audit committee varies between 1 to 12 times with an average of 4 times per annum.

Thus, the results for the descriptive statistics show that French companies have a board of directors or supervisory board that does not exceed 18 members, with a minimum average of 4 and 10. This coincides with the provisions of the Article L225-17 of the French Commercial Code.

Table 2. Descriptive statistics

\begin{tabular}{lllll}
\hline & Mean & Min. & Max. & St.Dev. \\
\hline ROA (\%) & -0.147 & -93.79 & 0.42 & 4.197 \\
ROE (\%) & 0.126 & -12.21 & 14.43 & 0.983 \\
IND_AC & 0.595 & 0.166 & 1 & 0.238 \\
SIZE_AC & 3.56 & 2 & 7 & 1.053 \\
COM_AC & 0.477 & 0.142 & 1 & 0.214 \\
ACT_AC & 4.18 & 1 & 12 & 1.754 \\
BIG4 & 0.358 & 0 & 1 & 0.479 \\
SIZE_B/S & 10.802 & 4 & 21 & 3.609 \\
SIZE_ENT & 14.631 & 10.13 & 18.92 & 1945 \\
END_ENT & 47.461 & -1550 & 5162.950 & 261.165 \\
\hline
\end{tabular}

Regression requires the absence of a multi-collinearity problem between the independent variables introduced into a same model. Indeed, Kennedy (1985) provides a $r=0.8$ to decide on a serious problem of collinearity between the independent variables which are included in the regression model.

The following Pearson correlation matrix shows that the degree of correlation between the different independent variables is moderated which implies the absence of the multi- collinearity problem between variables.

Table 3. Matrix of correlation between the explanatory variables

\begin{tabular}{lllllllll}
\hline & IND_AC & SIZE_AC & COM_AC & ACT_AC & BIG4 & SIZE_B/S & SIZE & DEBT \\
IND_AC & 1 & & & & & & & \\
SIZE_AC & $-0,062$ & 1 & & & & & & \\
COM_AC & $0,181^{* *}$ & $-0,354^{* *}$ & 1 & & & & & \\
ACT_AC & $0,153^{* *}$ & 0,331 & $-0,012$ & 1 & & & & \\
BIG4 & $0,200^{* *}$ & $0,208^{* *}$ & $-0,120^{*}$ & $0,326^{* *}$ & 1 & & & \\
SIZE_B/S & 0,100 & $0,373^{* *}$ & $-0,015$ & $0,292^{* *}$ & $0,367 * *$ & 1 & & \\
SIZE & $0,241^{* *}$ & $0,472^{* *}$ & $-0,095$ & $0,370^{* *}$ & $0,460^{* *}$ & $0,684^{* *}$ & 1 & \\
DEBT & $-0,032$ & 0,055 & $-0,047$ & 0,045 & 0,071 & 0,109 & $0,189^{* *} 1$ \\
\hline
\end{tabular}

**The correlation is significant at $1 \%$ and $*$ The correlation is significant at $5 \%$. 
To meet our main hypothesis, we perform an analysis of the empirical model by testing the performance through two dependent variables by conducting a comparative study of patterns measured by these variables in order to ensure the robustness of the results.

\subsection{Committee Adoption Regression Results}

The first model based on the ROE presents an adjusted $\mathrm{R}^{2}$ of $24.7 \%$ which proves a good adjustment quality. Table 2 shows that the variable "Adoption of the Audit Committee" has no more effect on the performance measured by ROE (Rao and Palaniappan, 2017). This result can be explained by the fact that most French companies voluntarily already adopt the Audit Committee (Piot, 2001; Thiery-Dubuisson, 2002).

What makes the legal establishment of the committee have no significant effect on the company's financial performance and confirms our hypothesis $\mathrm{H} 1$.

The second model also shows a non-significant relationship between the adoption of the audit committee and company performance as measured by ROA and which can also be explained by the strong voluntary adoption of the Audit Committee after publication of Viénot reports (Saada, 1998).

We show that Hypothesis 1 is rejected across the two models. We conclude that the mandatory adoption of the audit committee has no impact on the performance indicators in French companies since they have proceeded to the voluntary establishment of the audit committees before the entry into force of the 2008's law.

Regarding the control variables, Table 4 shows that the size of the board has a significantly negative effect at $1 \%$ on the financial performance of listed French companies measured by ROA. This result is confirmed by several researchers such as Kini, Kracaw and Mian (1995), Mak and Kusnadi (2005), Ghosh (2006) and Garg (2007). A small board makes more difficult to form coalitions and this situation reflect more effective control over managers.

Similarly, the variable "quality of external audit" has a significantly negative effect at $1 \%$ on the company's performance. So when the external auditor is a Big Four, the financial performance of French companies decreases (Demski, FitzGerald, Ijiri, Ijiri and Lin, 2006).

This result reinforces the substitution hypothesis proposed by Williamson (1983) and Fernández and Arrondo (2005). They noticed the existence of substitutability between the reputation of the external audit and the percentage of independence of the board of directors.

In addition, the "Company size" variable has a positive coefficient of 0.609 which shows that large companies are the most performing (Sridharan and Marsinko, 1997; Gurusamy, 2017).

After explaining the impact of the adoption of an audit committee on the performance of French companies, we will proceed in our second investigation to an analyzing the impact of the characteristics of audit committees on the performance

Table 4. Results of empirical models

\begin{tabular}{|c|c|c|c|c|c|c|c|}
\hline \multirow{2}{*}{ Variables } & \multirow{2}{*}{ Expected sign } & \multicolumn{3}{|l|}{ ROE } & \multicolumn{3}{|l|}{ ROA } \\
\hline & & Coeff. & $\mathbf{T}$ & Sig & Coeff. & $\mathbf{T}$ & Sig \\
\hline ADOP. & $+/-$ & -0.122 & -0.855 & 0.393 & -0.06 & -0.087 & 0.931 \\
\hline SIZE_B/S & - & -0.019 & -1.303 & 0.193 & -0.218 & -3.092 & $0.002 * *$ \\
\hline BIG 4 & - & -0.081 & -0.906 & 0.365 & -1.069 & -2.458 & $0.014 * *$ \\
\hline SIZE & + & 0.047 & 1.703 & $0.089 *$ & 0.609 & 4.503 & $0.000 * *$ \\
\hline LD & + & -0.002 & -12.904 & $0.000 * *$ & -0.027 & -0.152 & 0.88 \\
\hline \multicolumn{2}{|c|}{ The Constant } & -0.122 & -0.355 & 0.723 & -6.281 & -3.746 & $0.000 * *$ \\
\hline \multicolumn{2}{|l|}{$\mathbf{N}$} & 500 & & & 500 & & \\
\hline \multicolumn{8}{|c|}{-2Log probability } \\
\hline \multicolumn{8}{|c|}{ Classification rate $(\%)$} \\
\hline \multicolumn{8}{|c|}{ R2 of Naglkerke } \\
\hline \multicolumn{2}{|c|}{ Variation of $F$} & \multicolumn{3}{|l|}{33.694} & \multicolumn{3}{|l|}{4.537} \\
\hline \multicolumn{2}{|l|}{$\mathbf{R}^{2}$} & \multicolumn{3}{|l|}{0.504} & \multicolumn{3}{|l|}{0.21} \\
\hline \multicolumn{2}{|l|}{$\mathbf{R}^{2}$ adjusted } & \multicolumn{3}{|l|}{0.247} & \multicolumn{3}{|l|}{0.034} \\
\hline
\end{tabular}

*.Significant in a level of confidence at $10 \%$;**. Significant in a level of confidence at $1 \%$ 
Table 5 shows the results of two models ROE and ROA using the same explanatory variables for all models.

The table shows the three indicators to qualify the overall model which are essentially -2Log probability, the rate of correct classification and $\mathrm{R}^{2}$ Nagelkerke. These criteria are indicators of the overall connection between the dependent variable and the explanatory variables.

\subsection{Discussions}

\section{Model 1 ROE}

The table 5 shows that $\mathrm{R}^{2}$ adjusted coefficient is $16.9 \%$. So we can say that the explanatory power of this model is significant.

The table indicates that the variable "Independence of the members of the Audit Committee" is significantly negative at a level of $1 \%$. This result invalidates the hypothesis $\mathrm{H} 2$ and confirms the results of Brown and Caylor (2006) and Gurusamy, (2017). It's explained by high professional fees asked from independent members of board which has a negative impact on the performance. Aldamen, Duncan, Kelly, McNamara and Nagel (2012) showed this negative relationship in period of financial crisis. According to table 5, the size of the audit committee, the financial expertise and the number of meetings have no impact on the performance as measured by the ROE. These results are aligned with the studies of Al Matrooshi, Al-Sartawi, Sanad (2016), Gurusamy (2017) and Rao and Palaniappan (2017).

Regarding the control variables, the "Size of the board of directors" presents a significantly negative coefficient at the $1 \%$ level, which shows that increasing the size of the board negatively influences the performance of French companies (Eisenberg, Sundgren and Wells, 1998).

Similarly, the variable "Level of debts" is significantly negative at a level of $1 \%$, which confirms that the increase in debt has a negative effect on the financial performance of French companies (Sridharan and Marsinko, 1997).

In addition, the variable "Size of the company" has a positif coefficient and is statistically significant at the $1 \%$ level which proves that increasing the size of French companies positively impacts their performance (and Schiehll Bellavance, 2009, Gurusamy, 2017). However, the variable "Audit Quality" has no effect on the financial performance of the company (Noubbigh, 2008).

Model 2 ROE, allows us to conclude that only the independence of the audit committee significantly negative impact the financial performance of listed French companies.

\section{Model 2 ROA}

This model show three statistically significant variables "Independence of the Audit Committee", "Size of the Audit Committee" and "Diligence of Audit Committee".

Indeed, the variable "Independence of the Audit Committee" variable is statistically negative.

This result (confirmed by ROE model) proves that the independence of a member of the audit committee reduce the performance of French companies. This conclusion confirms the results obtained by the ROE model.

Similarly, the variable "Size of the Audit Committee" has a negative coefficient and is statistically significant at the 5\% level. This shows that the size of the audit committee negatively influences the financial performance of listed French companies. This confirms the hypothesis $\mathrm{H} 3$ and can be explained by the increase in the professional fees of the Audit Committee (Yermack, 1996; Karamanou and Vafeas, 2005; Aldamen, Duncan, Kelly McNamara and Nagel, 2012).

As well, the results indicate that the coefficient of the variable "Diligence Audit Committee" is significantly negative at a level of 5\%. This is explained by the fact that when the audit committee meets frequently, the company's performance decreases. This not validates the hypothesis H5. Thus, the number of meetings can be beneficial for the company if only the benefits gained exceed the costs. Based on the agency's theory, the effectiveness of the meetings of the audit committees depends on costs.

Regarding financial expertise, it has no impact on performance (lisic,Neal, zhang and zhang, 2016). Likewise, the size of the board and the quality of the audit has no impact on the performance measured by the ROA. It's explained by the fact that the number of expert audit committees does not automatically entrain more effective monitoring.

Model ROA proves that independence, size and frequency of the committee meetings negatively affect the financial performance of listed French companies (H3 confirmed). 
Table 5. Regressions results of Audit committee characteristics

\begin{tabular}{|c|c|c|c|c|c|c|c|}
\hline \multirow{2}{*}{ Variables } & \multirow{2}{*}{$\begin{array}{l}\text { expected } \\
\text { sign }\end{array}$} & \multicolumn{3}{|c|}{ Model 1 ROE } & \multicolumn{3}{|c|}{ Model 2 ROA } \\
\hline & & $\overline{\mathbf{A}}$ & $\mathbf{T}$ & Sig & $\mathbf{A}$ & $\mathbf{T}$ & Sig \\
\hline IND_AC & + & -0.412 & -2.286 & $0.023 * *$ & -0.032 & -1.907 & $0.057 * *$ \\
\hline SIZE_AC & - & -0.060 & -1.526 & 0.128 & -0.008 & -2.275 & $0.024 * * *$ \\
\hline COM_AC & + & -0.041 & -0.201 & 0.841 & -0.011 & -0.583 & 0.560 \\
\hline ACT_AC & - & 0.012 & 0.476 & 0.634 & -0.006 & -2.450 & $0.015^{* * *}$ \\
\hline BIG4 & - & -0.002 & -0.021 & 0.983 & 0.005 & 0.522 & 0.602 \\
\hline SIZE_B/S & - & -0.032 & -2.097 & $0.037 * * *$ & 0.001 & 0.695 & 0.488 \\
\hline SIZE & + & 0.113 & 3.639 & $0.000 * * *$ & 0.002 & 0.653 & 0.514 \\
\hline LD & + & -0.003 & -7.844 & $0.000 *$ & $-2,41 \mathrm{E}-05$ & -0.793 & 0.461 \\
\hline \multicolumn{2}{|l|}{ Constant } & -0.706 & -1.920 & $0.056^{* *}$ & 0.77 & 2.234 & 0.26 \\
\hline \multicolumn{2}{|l|}{$\mathbf{N}$} & \multicolumn{3}{|l|}{300} & \multicolumn{3}{|l|}{300} \\
\hline \multicolumn{2}{|c|}{-2Log probability } & \multicolumn{3}{|l|}{ - } & \multicolumn{3}{|l|}{ - } \\
\hline \multicolumn{2}{|c|}{ Classification rate $(\%)$} & \multicolumn{3}{|l|}{-} & \multicolumn{3}{|l|}{-} \\
\hline \multicolumn{2}{|c|}{$\mathbf{R}^{2}$ de Naglkerke } & \multicolumn{3}{|l|}{-} & \multicolumn{3}{|l|}{-} \\
\hline \multicolumn{2}{|c|}{ Variation og $\mathbf{F}$} & \multicolumn{3}{|l|}{8.614} & \multicolumn{3}{|l|}{2.195} \\
\hline \multicolumn{2}{|l|}{$\mathbf{R}^{2}$} & \multicolumn{3}{|l|}{0.438} & \multicolumn{3}{|l|}{0.239} \\
\hline \multicolumn{2}{|l|}{$\mathbf{R}^{2}$ adjusted } & \multicolumn{3}{|l|}{0.168} & \multicolumn{3}{|l|}{0.031} \\
\hline
\end{tabular}

IND_AC : The independence of audit committee, SIZE_AC : The size of the audit committee, COM_AC : The competence of the audit committee, ACT_AC : the activity of the audit committee,BIG4 : the quality of the external audit ,SIZE_B/S : the size of the board or supervisory SIZE : the size of the company, LD_: the level of debt

* Indicates significant at the confidence level of 10\%; ** Indicates significant at the confidence level of. 5\%;

*** Indicates significant at the confidence level of $1 \%$.

\section{Conclusion}

After the enactment of Ordinance No. 2008-1278 of December 8th, 2008, the establishment of audit committees in France has become a requirement for listed companies. This led us to study the impact of the legal establishment of the audit committee on the performance of French companies. Our empirical results through two regression models confirm that the appearance of a legal text that requires the establishment of the committee has no significant effect on the company's performance. This joins the results of Rao and Palaniappan, (2017) in the Indian context and can be explained by the strong voluntary adoption of the audit committee following the publication of the Viénot Reports (Saada, 1998 Piot, 2001; Thiery-Dubuisson, 2002).

Our research extend later to test the impact of the main features of the audit committee namely the independence, the size, the skill and the diligence on the performance of the French company.

We find that the independence of the audit committee have a negative impact on the performance measured by ROE and ROA. It's explained by high professional fees asked from independent members of board which has a negative impact on the performance (Caylor Brown, 2006; Aldamen, Duncan, Kelly, McNamara and Nagel, 2012).

We conclude also that the size, the financial expertise and the diligence of the audit committee have no impact on the financial performance of listed French companies when the performance is measured by ROE (Karamanou and Vafeas, 2005; Aldamen, Duncan, Kelly McNamara and Nagel, 2012; Gurusamy, 2017).

On the other side, the size and diligence of audit committee have a negative impact on performance as measured by the ROA, (AlMatrooshi, Al-Sartawi, Sanad, 2016; Gurusamy, 2017 and Rao and Palaniappan, 2017). This result can be explained by the increase in the professional fees of the Audit Committee (Aldamen, Duncan, Kelly McNamara and Nagel, 2012) and the fact that the number of meetings can be beneficial for the company if only the benefits gained exceeds the costs. 
The results of this study motivate us to accomplish a further study which explains the negative impact of the independence of audit committees on the performance and the role of internal audit and other governance concept.

\section{References}

Abbott, L. J., Parker, S., Peters, G.F. \& Raghunandan, K. (2003). The association between audit committee characteristics and audit fees. Auditing: A Journal of Practice and Theory, 22(2), 17-32. https://doi.org/10.2308/aud.2003.22.2.17

Abernathy, J. L., Beyer, B., Masli, A., Stefaniak, C. (2014). The Association between Characteristics of Audit Committee Accounting Experts, Audit Committee Chairs, and Financial Reporting Timeliness. Advances in Accounting, 30(2), 283-297. https://doi.org/10.1016/j.adiac.2014.09.001

Aldamen, H., Duncan, K., Kelly, S., McNamara, R., \& Nagel, S. (2012). Audit committee characteristics and firm performance during the global financial crisis. Accounting \& Finance, 52(4), 974-1000. https://doi.org/10.1111/j.1467-629X.2011.00447.x

AlMatrooshi, S., Al-Sartawi,A., Sanad, Z. (2016) . Do audit committee characteristics of Bahraini listed companies have an effect on the level of internet financial reporting? Corporate Ownership and Control Journal, 13(2), 130-146. https://doi.org/10.22495/cocv13i3p12

Al-Mamun, A., Yasser, Q.R., Rahman, M.A., Wickramasinghe, A. \& Nathan, T.M. (2014). Relationship between audit committee characteristics, external auditors and economic value added (EVA) of public listed firms in Malaysia. Corporate Ownership \& Control, 12, 899-910. https://doi.org/10.22495/cocv12i1c9p12

Arslan, M., Zaman, R., Malik, K., Mehmood, A. (2014). Impact of CEO Duality and Audit Committee on Firm Performance: A Study of Oil \& Gas Listed Firms of Pakistan. Research Journal of Finance and Accounting, 5, 151-156.

Beasley, M.S., Carcello, J.V., Hermanson, D.R., \& Lapides, P.D. (2000). Fraudulent Financial Reporting: Consideration of Industry Traits and Corporate Governance Mechanisms. Accounting Horizons, 14(4), 441-454. https://doi.org/10.2308/acch.2000.14.4.441

Bédard, J., \& Gendron, Y. (2010). Strengthening the financial reporting system: Can audit committees deliver? International Journal of Auditing, 14(2), 174-210. https://doi.org/10.1111/j.1099-1123.2009.00413.x

Brown, L.D., \& Caylor, M.L. (2006). Corporate governance and firm valuation. Journal of Accounting and Public Policy, 25, 409-434. https://doi.org/10.1016/j.jaccpubpol.2006.05.005

Chen, F. \& Li, Y. (2013). Voluntary adoption of more stringent governance policy on audit committees: theory and empirical evidence. The Accounting Review, 88, 1939-1969. https://doi.org/10.2308/accr-50541

Chong, Y.L. (2005). Economic theory and the East Asian region. The Singapore Economic Review, 50, 495-512. https://doi.org/10.1142/S0217590805002177

Chtourou, S.M., Bédard J., \& Courteau L. (2004). The effect of audit committee expertise, independance, and activity on aggressive earnings management. Auditing: A Journal of Practice and Theory, 23(2), 13-35. https://doi.org/10.2308/aud.2004.23.2.13

Connell, V,O., \& N. Cramer. (2010). The Relationship between Firm Performance and Board Characteristics in Ireland. European Management Journal, 28(1), 387-399. https://doi.org/10.1016/j.emj.2009.11.002

Dao, M., Huang, H.-W. \& Zhu, J. (2013). The effects of audit committee members' age and additional directorships on the cost of equity capital in the USA. European Accounting Review, 22, 607-643. https://doi.org/10.1080/09638180.2012.739823

Demski, J.S., FitzGerald, S.A., Ijiri, Y., Ijiri Y., \& Lin, H. (2006). Quantum information and accounting information: their salient features and conceptual applications. Journal of Accounting and Public Policy, 25(4), 435-464. https://doi.org/10.1016/j.jaccpubpol.2006.05.004

DeZoort, F. T., Hermanson, D.R., Archambeault, D.S., \& Reed,S.A. (2002). Audit committee effectiveness: A synthesis of the empirical audit committee literature. Journal of Accounting Literature, 21, 38-75.

Dinu, V., Nedelcu (Bunea), M., (2015). The Relationship between the Audit Committee and the Financial Performance, the Asset Quality and the Solvency of Banks in Romania. Transformations in Business and Economics, 14(35), 161-173. 
Eichenseher, J. W., \& Shields, D. (1985). Corporate Director Liability and Monitoring Preferences. Journal of Accounting and Public Policy, 4, 13-31. https://doi.org/10.1016/0278-4254(85)90010-9

Eisenberg, T., Sundgren, S., \& Wells, M.T. (1998). Larger board size and decreasing value in small firms. Journal of Financial Economics, 48(1), 35-54. https://doi.org/10.1016/S0304-405X(98)00003-8

Fernández , C., \& Arrondo, R. (2005). Alternative Internal Controls as Substitutes of the Board of Directors. $\begin{array}{lll}\text { Corporate governance an international review, } & \text { 13(6), 856-866. }\end{array}$ https://doi.org/10.1111/j.1467-8683.2005.00476.x

Garg, A.K. (2007). Influence of Board Size and Independence on Firm Performance: A Study of Indian Companies. Vikalpa, 32(3), 39-60.

Godard, L. (2002). La taille du conseil d'administration : déterminants et impact sur la performance. Revue Sciences de Gestion, 33, 125-148.

Ghosh, S. (2006). Do Characteristics affect Corporate Performance? Firm level Evidence for India. Applied Economics Letters, 13(7), 453-443. https://doi.org/10.1080/13504850500398617

Guo, R.J., \& Yeh, Y.H. (2014). The composition and effectiveness of audit committees in the presence of large controlling shareholders. Journal of Applied Corporate Finance, 26, 96-104. https://doi.org/10.1111/jacf.12085

Gurusamy, P. (2017). Board characteristics, audit committee and ownership structure influence on firm performance of manufacturing firms India. International Journal of Business and Economics Research, 6(4), 73-87. https://doi.org/10.11648/j.ijber.20170604.16

Hamdan, A.M., Sarea, A.M. \& Reyad, S.M.R. (2013). The impact of audit committee characteristics on the performance. Evidence from Jordan. International Management Review, 9, 32-42.

Heenetigala, K., \& Armstrong, A.F. (2011). The Impact of Corporate Governance on firm performance in an unstable economic and political environment: Evidence from Sri Lanka. Financial Markets and Corporate Governance, Conference du 13 décembre 2011. https://doi.org/10.2139/ssrn.1971927

Kallamu \& Saat. ( 2015). Audit committee attributes and firm performance: evidence from Malaysian finance companies. Asian Review Of Accounting, 23(1).

Karamanou, I., \& Vafeas,N. (2005). The association between corporate boards, audit committees, and management earnings forecasts: An empirical analysis. Journal of Accounting Research, 43(1), 453-486. https://doi.org/10.1111/j.1475-679X.2005.00177.x

Kennedy, P. (1985). A guide to econometrics. Basil Blackwell, Southampton.

Kini, O., Kracaw, W., \& Mian, S. (1995). Corporate takeovers, firm performance, and board composition. Journal of Corporate Finance, 1(3)(4), 383-412. https://doi.org/10.1016/0929-1199(94)00011-I

Lee, T., \& Stone, M. (1997). Economic agency and audit committee: responsibilities and membership composition. International Journal of Auditing, (1) (2), 97-116.

Lisic , L., Neal,T., zhang, X., zhang, Y. (2016). CEO power, internal control quality, and audit committee effectiveness in substance versus in form Contemporary accounting research, 33(3). https://doi.org/10.1111/1911-3846.12177

Mak, Y. T., \& Kusnadi, Y. (2005). Size really matters: Further evidence on the negative relationship between board size and firm value. Pacific-Basin Finance Journal, 13(3), 301-318. https://doi.org/10.1016/j.pacfin.2004.09.002

Maraghni, I., Nekhili, M. (2014). La diligence du comité d'audit dans les entreprises françaises : question d'indépendance ou de compétence ? Comptabilité - Contrôle-Audit, 20, 144.

McDaniel, L., Martin, R. D., \& Maines, L.A., (2002). Evaluating Financial Reporting Quality: The Effects of Financial Expertise vs. Financial Literacy. The Accounting Review, 77, 139-167. https://doi.org/10.2308/accr.2002.77.s-1.139

Menon, K., \& Williams, J.D. (1994). The Use of Audit Committees for Monitoring. Journal of Accounting and Public Policy, 13(1), 121-139. https://doi.org/10.1016/0278-4254(94)90016-7

Nuryanah, S. \& Islam, S.M.N. (2011). Corporate governance and performance. Evidence from an emerging market. Malaysian Accounting Review, 10, 17-42. 
Piot, C. (2001). Agency costs and audit quality: Evidence from France. The European Accounting Review, 10(3), 461-499. https://doi.org/10.1080/713764630

Piot, C., \& Janin, R. (2007). External auditors, audit committees and earnings management in France. European Accounting Review, 16(2), 429-454. https://doi.org/10.1080/09638180701391030

Rao, S., Palaniappan, G. (2017). Board independence, audit committee effectiveness and firms performance: An empirical evidence of manufacturing firms in India. Imperial journal of interdisciplinary research, 3(1), 883-890.

Rezaee Zabihollah. (2009). Corporate Governance and Ethics. John Wiley and Sons, Inc, USA, 429 pages.

Saada, T. (1998). Les comités d'audit en France : un an après le rapport Viènot. Finance, Contrôle, Stratégie, (1)(3), 159-184.

Saibaba, M.D., \& Ansari, V.A. (2011). A Study of CEO Duality,Audit Committees and Corporate Governance in Companies Listed in BSE 200 Index. Journal of Corporate Governance, (3), 44-51, 2011.

Saibaba, M.D., \& Ansari, V.A. (2013). Audit committees, board structures and firm performance: a panel data study of BSE 30 companies. Journal of Accounting Research \& Audit Practices, 12, 19-29.

Schiehll, E., \& Bellavance, F. (2009). Boards of directors, CEO ownership, and the use of non_financial performance measures in the CEO bonus plan. Corporate Governance: An International Review, 17(1), 90-106. https://doi.org/10.1111/j.1467-8683.2008.00723.x

Singhvi, M., Rama, D.V. \& Barua, A. (2013). Market reactions to departures of audit committee directors. Accounting Horizons, 27, 113-128. https://doi.org/10.2308/acch-50284

Sultana, N. Singh, H.,Mitchell , J., Zahn , V. (2015). Audit Committee Characteristics and Audit Report Lag. international journal of auditing, 2(19), 72-87. https://doi.org/10.1111/ijau.12033

Sridharan, V., \& Marsinko, A. (1997). CEO duality in the paper and forest products Industry. Journal of Financial and Strategic Decisions, 10(1), 59-65.

Stewart, J., \& Munro, L. (2007). The impact of audit committee existence and audit committee meeting frequency on the external audit: perceptions of Australian auditors. International Journal of Auditing, 11(1), pp. 51-69. https://doi.org/10.1111/j.1099-1123.2007.00356.x

Thiéry-Dubuisson, S. (2002). Exigences actionnariales et réseaux d'administrateurs : à quoi répond la mise en place des comités d'audit en France? Comptabilité-Contrôle-Audit, 8(1), 129-150. https://doi.org/10.3917/cca.081.0129

Vlaminck, N., Sarens, G,N. (2015). The relationship between audit committee characteristics and financial statement quality: evidence from Belgium. Journal of Management Governance, 1(1), 145-166|. https://doi.org/10.1007/s10997-013-9282-5

Velte, P. (2017). The link between audit committee, corporate governance quality and firm performance: a literature review. Corporate Ownership \& Control,14(4), 15-31. https://doi.org/10.22495/cocv14i4art2

Viénot, M. (1999). Rapport du comité sur le gouvernement d'entreprise présidé par M. Marc Viénot. AFEP and MEDEF document, July, Paris.

Weir, C., Laing, D., McKnight, P.J., (2002). Internal and external governance mechanisms: Their impact on the performance of large UK Public Companies. Journal of Business Finance and Accounting, 29(5) (6), 579-611. https://doi.org/10.1111/1468-5957.00444

Yang, J.S., \& Krishnan J. (2005). Audit committees and quarterly earnings Management. International Journal of Auditing, 9(3), 201-219. https://doi.org/10.1111/j.1099-1123.2005.00278.x

Yasser, Q.R., Entebang, H., Abu Mansor, S. (2011). Corporate governance and firm performance in Pakistan: The case of Karachi Stock Exchange (KSE). Journal of Economics and International Finance, 3(8), 482-491.

Yermack, D. (1996). Higher market valuation companies with a small board of Directors. Journal of Financial Economics, 40(2), 185-211. https://doi.org/10.1016/0304-405X(95)00844-5 